\title{
Nature of Diamonds, Melts and Fluids in the Ring Structures: Endogeneous Explosion vs. Impact Process
}

Iouchko, N.A. ${ }^{1}$, Kremenetsky, A.A. ${ }^{1}$, and Kouznetsov, I.I. ${ }^{2}$

1. Institute of Mineralogy, Geochemistry and Crystal Chemistry of Rare Elements, 121357, Moscow, Russia

2. Research Industrial Company GERS, 119121, Moscow, Russia

Kimberlite volcanism usually tends to large platform structures characterized by lasting elevation (cratons, arches and anteclises). Geological and geophysical studies here revealed the vial-shaped ring structures (RS) ranging in diameter from 10 to $100 \mathrm{~km}$, occasionally with a rise in the middle. The ring structures are filled with clasts of the basement crystalline rocks and the cover sediments, as well as various vitreous rocks and the melt rock bodies. The basement rocks are brecciated and are either cemented by the melt matrix, or host lenses, veins and irregular bodies of the melt rocks. Some RS are diamoniferous (e.g., Popigai, Siberia, Nordlinger Ries, Germany, and Puchezh-Katunki, Russia at the Russian Platform).

When first encountered, these structures were believed to be related to the explosive processes that accompanied basic and alkaline-basic volcanism in tectinically activated segments of platforms. Presumably, a flow of deep reducing fluids genetically related to overheated volatiles-rich alkaline basaltic magma produces a diapir of melted fluidized material carriying a high-pressure gaseous phase. Along with ascent of such diapirs, explosions occurred, being provoked by sharply dropping pressure and formation of explosive gaseous compounds and mixtures (Vaganov et al., 1985). However, discoveries of the high-pressure silica modifications, stishovite and coesite, that form at 10-45 GPa, as well as diamond-lonsdaleite paramorphs enabled the impact-explosive notion on the nature of the ring structures and classificate the structures as meteoritic craters and astroblemes. Compression wave and shock decompression caused by meteoritic impact induce brecciation, impact metamorphism and partial melting of the target rocks, with subsequent hydrothermal alteration by solutions circulating in the impact-heated rocks. Presumably, intensive impacts which occur in areas of high geothermal gradient may ensure formation of large melt masses that form the injection intrusives in the basement of the craters (e.g. Sudbury; Dietz, 1972). Besides, the shock wave could have activated deep lithosphere by decreasing the lithostatic loading in the lower crust and mantle during the course of relaxation, and additional after-shock heat generation that triggered magmatism and percolation of the juvenile fluids towards the upper parts of the crust. Here the fluids could accumulate in permeable brecciated and fissured impact-caused zones. This is the way the gas and condensate reservoires could be formed. Such accumulations of natural hydrocarbons has been predicted to occur in the Siljan Ring, Sweden. However, no reservoires have been disclosed by the Gravberg DDH (6337 m deep); only showings of methane and heavy hydrocarbons have been observed. Thus, origin of the ring structures discovered in zones of kimberlite magmatism is significant as 
in interpretation of the activated platforms' tectonic evolution, as well as in estmation of mineragenic potential of such areas.

The latter purpose motivated us to study one of the large ring structures in the European Russia, the Puchzh-Katunki RS that lies in the Russian Platform north of Nizhnii Novgorod. Two structural stages constitute the sequence of the upper crust: a sedimentary cover ( 1.5 to $2 \mathrm{~km}$ thick) and Precambrian crystalline basement. The RS is a flat sub-isometric 'vial' , $80 \mathrm{~km}$ in diameter, with a dome-shaped central rise, 6 to $10 \mathrm{~km}$ in diameter; height of the rise (relatively to the bottom of the structure) is 1.6 to $1.9 \mathrm{~km}$. The rise is surrounded by a $2 \mathrm{~km}$-deep trench and a ring terrace.Inner part of the depression is filled by coarse and fine-clastic polimictic breccia constituted by fragments of basement and cover rocks, as well as vitreous and pumice varieties. Basement of the RS is constituted by Precambrian plagiogneiss, schists and amphibolites; thin dolerite dykes (Pz?) has been encountered here.These rocks are brecciated and fissured; with numerous indications of impact metamorphism: planar elements, diaplectic minerals and glass, coesite, etc. The breccia clasts are frequently cemented by impact melt, either the latter forms a network of thin veinlets $(0.5$ to $2 \mathrm{~cm}$ ) or forms individual lenses (up to $3 \mathrm{~m}$ thick in the top of the basement or up to $10-30 \mathrm{~m}$ in the polymictic breccia). Origin of the Puchezh-Katunki RS is sharply disputable: the versions are as follows:

1. An explosion pipe localised at the NE zone of the basaltic volcanism in the Russian Platform. Age of the RS corresponds to a period of almost total elevation of the platform above the sea level; basic and alkaline basic volcanism is inherent in the time interval (Vardanyants, 1961).

2. An explosive structure was formed by a series of the high-energy explosions caused by pressurized hydrogen fluids that rapidly ascended to the day surface immediately from the core (deep reducing degassing); these events were preceeded by a lasting uplifting of an arch motivated by the orogenic activation of the Russian Platform. The near-surface explosions within the elevation produced a basin filled by explosive breccia, as well as a series of diamondiferous breccia dykes and explosion pipes in the basement. Emplacement of basalt and ultrabasic melts followed. As Marakushev et al. (1993) believe, endogeneous impact processes that produce large RS immediately precede not only kimberlite magmatism, but intrusive and volcanic activities as well.

3. A buried meteoritic crater or an astrobleme formed in Jurassic time. Cosmogenic origin of the Puchezh-Katunki RS is based upon its morphology and anatomy, peculiarities of the target rock dislocations, and numerous manifestations of the impact metamorphism and melting of the rocks (Firsov, 1965; Masaitis et al., 1980). As stated, the high-temperature impact melts originated at the contact of the meteoritic body and the target penetrated the basement rock along contemporaneous radial fractures to depth about $3.5 \mathrm{~km}$, thus forming the injection intrusives and causing thermal influence onto the surrounding rocks. The post-impact hydrothermal alterations were caused by the waters of atmospheric origin circulating in the heated 'coptoclastites' (Masaitis et al., 1994).

The Vorotilovsk DDH driven within the center of the Puchezh-Katunki RS disclosed the impact metamorphosed sequence to $5374 \mathrm{~m}$. Mineralogical, geochemical and isotopic 
(Rb-Sr, ${ }^{3} \mathrm{He}-{ }^{4} \mathrm{He}$ ) studies of the source rocks and products of their impact metamorphism and melting have been carried out here. The results obtained are as follows:

1. The impact metamorphism in the basement rocks (550 to $5374 \mathrm{~m}$ interval) is uneven, but in general its grade and scale decreases downward. Along the depth range studied, the impact and thermal alterations in the rocks occurred isochemically. Variations in the geochemical field of the RS were controlled by the source rock features as products of regional metamorphism, as well as development of the postimpact hydrothermal mineralization.

2. By and large, the melt impactites inherit the source rock features, as displayed by identity of their petrochemical characteristics. In case when mixed breccias melt, averaged andesitic rocks are produced. Selective melting results in enrichment of the first portions of melt in alkali, siderofiles, TR and Ta. Separation of the post-impact fluid leads to relative accumulation of $\mathrm{Ti}, \mathrm{Nb}, \mathrm{Zr}$, and $\mathrm{Fe}$ in the residual.

3. In the upper part of the basement the impact melts undergo retrograde boiling during the course of the shock decompression; separation of the fluid rich in $\mathrm{K}, \mathrm{Na}$, $\mathrm{Li}, \mathrm{Rb}, \mathrm{Sr}, \mathrm{Mo}, \mathrm{B}$, and $\mathrm{Hg}$ occurs. This fluid mixes with the pore waters and causes alterations in the overlying impact breccia; positive $\mathrm{Li}, \mathrm{Sr}, \mathrm{B}, \mathrm{Bi}, \mathrm{Pb}, \mathrm{Cu}, \mathrm{Be}, \mathrm{Ni}$ anomalies arise, whereas $\mathrm{Cr}, \mathrm{V}, \mathrm{Zn}, \mathrm{Ba}, \mathrm{Na}, \mathrm{K}, \mathrm{P}$, and $\mathrm{Ga}$ are removed and redistributed.

4. Proportion of impact diamonds that occur in allogeneous breccia to those in related melt impactites is $1: 3$; in minor quantities diamonds are observable at the upper contact of the basement in the impactite veinlets hosted by breccia (Bogatyrev, Selivanovskaya, Zairi, unpublished). Diamonds are small $(0.1$ to $0.25 \mathrm{~mm})$, flattened, and of pseudo-hexagonal habit. Diamonds represent finely textured poly-crystalline aggregates of cubic crystals, hexagonal lonsdailite (5 to 40\%), graphite, and chaoite; diamond-lonsdailite intergrowings are most common. These diamonds differ from kimberlite-hosted in higher refraction and index value, as well as dielectric constant, and in lower density.

5. Values of $\mathrm{I}^{0}{ }_{\mathrm{sr}}$ ratio in the sourse basement rocks $(0.704$ to 0.708$)$ and melt impactites, products of their impact-related alterations $(0.705$ to 0.709$)$ remain close at various depth levels within the RS; this is an indication of in situ origin. Low ${ }^{3} \mathrm{He} /{ }^{4} \mathrm{He}$ ratio $\left(1.9 \div 4.7 * 10^{-8}\right)$ comparable to that of the average continental crust value, indicates negligible influence of the mantle fluids.

6. Enhanced $\mathrm{I}_{\mathrm{Sr}}^{0}$ ratio values inherent in diamondiferous impactites are conditioned by formation of the latter at the account of the polymictic breccia melting within the crater. The breccia is constituted by fragments of the sedimentary cover: typical $\mathrm{I}_{\mathrm{Sr}}^{0}$ ratio here ranges from 0.720 to 0.738 . Taking into consideration the above mentioned morphologic and structural features of the impact diamonds, it seems possible to conclude that the diamond productivity of the rocks within the crater is controlled by presence of carboniferous sediments among the source rocks. Difference in the isotopic Sr composition of the crater impactites and those of the basement excludes 
considerable transport of diamondiferous sub-surface impact melts into the deep parts of the target.

The work was supported financially by RFBR (Project 95-05-14802)

\section{References}

Vaganov, V.I., Ivankin, P.F., Kropotkin, P.N., et al., 1985, Explosive ring structures of cratons and platforms: Moscow, Nedra, 200 p.*

Dietz R.S., 1972, Sudbury astrobleme, splash emplaced sub-layer and possible cosmogenic ores: Spec. Pap. Geol. Assoc. Canada, no.10, p.29-40.

Vardanyants, L.A., 1961, An explosive pipe in the central part of the Russian Platform: Izv. AN Arm. SSR, v.14, no.2, p.29-32.

Marakushev, A.A., Bogatyrev, O.S., Fenogenov, A.D., et al., 1993, Impactogenesis and volcanism: Petrologiya, v.1, no.1, p. 571-595.*

Firsov, L.F., 1965, On meteoritic origin of the Puchezh-Katunki crater: Geotektonika, no. 2, p. 106-108*

Masaitis, V.L., Danilin, A.N., Mashchak, M.S., et al., 1980, Geology of astroblemes:

Leningrad, Nedra, 231 p.*

Masaitis V.L., Mashchak M.S., Naumov M.V. et al., 1994, Large Astroblemes of Russia, St.Petersburg, VSEGEI, 33p.

Note: * in Russian. 